\title{
Genera Jamur Patogen dan Persentase Penyakit Bercak Daun yang ditemukan pada Pertanaman Sawi Hijau (Brassica juncea) di Desa Serang, Kecamatan Karangreja, Purbalingga
}

\author{
Nia Sri Hartatik, Eddy Tri Sucianto, Endang Sri Purwati \\ Fakultas Biologi, Universitas Jenderal Soedirman \\ Jalan dr. Soeparno 63 Purwokerto 53122 \\ Email: niasrii17@gmail.com
}

Rekam Jejak Artikel:
Diterima : $13 / 10 / 2020$
Disetujui : $13 / 12 / 2020$

\begin{abstract}
Green mustard (Brassica juncea) is an annual or horticultural plant of the Brassica genus. The purpose of this research is to knowledge the type of fungi that cause leaf spot disease on green mustard plants and to know the large percentage of leaf spot diseases caused by fungus on mustard greens in Serang Village, Karangreja District, Purbalingga. This research is used survey method by taking purposive random sampling at two different locations. The type of fungus that causes leaf spot disease on (B. juncea) mustard green can be identified by isolating the part of plants are sick then identified. Identification of fungi is doing by two stages of observation, that is observation macromorphological characters and micromorphological characters. Observation of macromorphological characters includes colony color, colony shape, the edge of colony shape and colony reverse color. Observation of the micromorphology character includes the presence of hyphae, hyphae (insulated or non-insulated), conidia shape, conidia color, additional devices and conidiophores. The next stage to find out the type of fungus that causes leaf spot disease is Koch's Postulate.The results obtained there is one type of disease in green mustard plants. Leaf spot is one of the diseases of mustard greens caused by the fungus Alternaria sp, with a frequency of leaf spot disease as many as 196 times, and the percentage of disease of 51,30\%.

Key Words : leaf spot, identification, mustard greens (Brassica juncea)
\end{abstract}

\begin{abstract}
Abstrak
Sawi hijau (Brassica juncea) merupakan tanaman semusim atau tanaman hortikultura dari marga Brassica. Tujuan penelitian ini adalah untuk mengetahui jenis jamur penyebab penyakit bercak daun pada tanaman sawi hijau dan untuk mengetahui besarnya persentase penyakit bercak daun yang disebabkan oleh jamur pada tanaman sawi hijau di Desa Serang, Kecamatan Karangreja, Purbalingga. Penelitian ini menggunakan metode survai dengan pengambilan sampel secara purposive random sampling pada dua lokasi yang berbeda. Jenis jamur yang menyebabkan penyakit bercak daun pada sawi hijau $B$. juncea, dapat diketahui dengan cara mengisolasi bagian tanaman yang sakit selanjutnya di identifikasi. Identifikasi jamur dilakukan dengan dua tahap pengamatan, yaitu pengamatan karakter makromorfologi dan karakter mikromorfologi. Pengamatan karakter makromorfologi meliputi warna koloni, bentuk koloni, bentuk tepi koloni dan warna sebalik koloni. Pengamatan karakter mikromorfologi meliputi ada tidaknya sekat pada hifa (hifa bersekat atau tidak bersekat), bentuk konidia, warna konidia, alat tambahan dan konidiofor. Tahapan selanjutnya untuk mengetahui jenis jamur penyebab penyakit bercak daun dilakukan Postulat Koch. Hasil penelitian yang diperoleh yaitu terdapat satu jenis penyakit jamur pada tanaman sawi hijau. Bercak daun adalah salah satu penyakit pada sawi hijau yang disebabkan oleh jamur Alternaria sp, dengan frekuensi penyakit bercak daun sebanyak 196 kali, dan persentase penyakit sebesar 51,30\%

Kata kunci : bercak daun, identifikasi, sawi hijau (Brassica juncea L).
\end{abstract}

\section{PENDAHULUAN}

Sawi hijau (Brassica juncea) adalah tumbuhan dari marga Brassica yang dimanfaatkan daunnya sebagai bahan makanan. Menurut Haryanto et al. (2007) sawi hijau bermanfaat untuk memperlancar pencernaan dan memperbaiki fungsi kerja ginjal. Marga Brassica mencakup beberapa spesies yang mirip satu sama lain. Di Indonesia penyebutan sawi biasanya mengacu pada sawi hijau. Selain itu terdapat pula sawi putih. Sawi adalah salah satu tanaman hortikultura yang memiliki nilai ekonomis tinggi. Sawi juga memiliki nilai gizi yang 
baik, karena mengandung karbohidrat 4,0 g, lemak $0,3 \mathrm{~g}$, protein $2,3 \mathrm{~g}$, kalsium $220 \mathrm{mg}$, fosfor $38 \mathrm{mg}$, besi 2,0 mg, vitamin A 1940,9 mg, vitamin B 0,1 $\mathrm{mg}$, dan vitamin C $102 \mathrm{mg}$, dalam setiap $100 \mathrm{~g}$ sawi (Sangadji, 2018).

Sawi hijau di Indonesia dibudidayakan pada dataran tinggi dan dataran rendah karena termasuk tanaman yang toleran terhadap suhu tinggi. Kebutuhan akan sawi hijau cenderung semakin meningkat seiring dengan peningkatan kebutuhan bahan pangan maupun sebagai bahan pemeliharaan kesehatan (Purnomo et al., 2012). Desa Serang merupakan salah satu desa di Kecamatan Karangreja Purbalingga yang berada di ketinggian $1.200 \mathrm{mdpl}$, sehingga cocok digunakan dalam pembudidayaan sawi hijau (Safitri, 2016). Permasalahan yang dialami petani dalam budidaya sawi hijau di Desa Serang, Purbalingga antara lain pengelolaan lahan pertanian yang belum maksimal yaitu sistem tanam tumpang sari dengan tanaman sejenis yang memicu munculnya penyakit, salah satunya adalah penyakit bercak daun sehingga dapat menurunkan produktivitasnya.

Menurut Pratap et al. (2016) penyakit bercak daun mempengaruhi tanaman pada semua tahap pertumbuhan. Gejala awal ditandai dengan munculnya bintik hitam, yang kemudian membesar dan berkembang menjadi bintik-bintik konsentris, berbentuk bulat, dengan berbagai ukuran. Bercak daun disebabkan oleh jamur salah satunya adalah jamur Alternaria sp. jamur patogen memiliki penyebaran luas di wilayah tropis seperti Indonesia. Serangan jamur patogen dalam aktivitasnya sangat dipengaruhi oleh cuaca. Kasus serangan berat sering terjadi pada musim hujan (Sutarman, 2017).

Menurut data Badan Pusat Statistik Kabupaten Purbalingga (2017) produksi sawi hijau di Desa Serang Kabupaten Purbalingga dari tahun 2014-2015 mengalami penurunan dari 4,8 ton/ha pada tahun 2014 menjadi 4,6 ton/ha pada tahun
2015 dan pada tahun 2016 produksi sawi meningkat kembali menjadi 12,26 ton/ha, dengan luas total lahan pertanaman sawi di purbalingga sekitar 40 ha. Penyebab penurunan produksi sawi hijau di Desa Serang salah satunya adalah yang disebabkan oleh jamur, tetapi tidak semua pertanaman sawi hijau (B juncea) di Desa Serang terinfeksi patogen pada bagian daun dan akarnya. Pertanaman sawi hijau yang menggunakan sistem tanam tumpang sari biasanya menunjukkan persentase penyakit yang lebih besar (Wangge \& Fowo, 2012). Munculnya jamur patogen pada tanaman sawi hijau di Desa Serang, Kecamatan Karangreja, Kabupaten Purbalingga dapat menimbulkan penurunan hasil panen yang merugikan petani. Menurut Rukmana (1994) agar tidak terjadi lagi penurunan hasil panen perlu dilakukan penelitian lebih lanjut mengenai penyakit bercak daun yang disebabkan oleh jamur patogen. Pengembangan budidaya sawi hijau memiliki prospek baik untuk mendukung upaya peningkatan pendapatan petani, peningkatan gizi masyarakat, perluasan kesempatan kerja, pengembangan agribisnis, peningkatan pendapatan negara melalui pengurangan impor dan memacu laju pertumbuhan ekspor.

Berdasarkan permasalahan diatas, maka perlu dilakukan penelitian dengan tujuan mengetahui jenis jamur yang menyebabkan penyakit bercak daun pada tanaman sawi hijau dan mengetahui besarnya persentase penyakit bercak daun yang di sebabkan oleh jamur pada tanaman sawi hijau di Desa Serang, Kecamatan Karangreja, Purbalingga.

Penelitian ini diharapkan dapat bermanfaat dalam memberikan informasi tentang jenis jamur penyebab penyakit dan persentase penyakit bercak daun pada pertanaman sawi hijau, sehingga dapat digunakan para petani dalam mencegah penurunan produktivitas atau meminimalisir kerugian hasil panen akibat infeksi jamur pada pertanaman sawi 
hijau ( $B$ juncea) di Desa Serang, Kecamatan Karangreja, Purbalingga.

\section{MATERI DAN METODE}

\section{Materi, Lokasi dan Waktu Penelitian}

Bahan yang digunakan dalam penelitian ini yaitu sampel tanaman sawi hijau (B. juncea), kentang, agar, dextrose, akuades, alkohol 70\% dan Chloramphenicol, sedangkan alat yang digunakan dalam penelitian ini adalah Laminar Air Flow (LAF), autoclave, mikroskop, kompor gas, panci, cawan petri, tabung reaksi, labu erlenmeyer, batang pengaduk, gelas ukur, object glass, cover glass, bunsen, pinset, jarum ose, scalpel, termoyhgrometer, soil tester, masker, wrapper, kertas label, kantong plastik, kapas, sprayer, alat tulis dan kamera.

Pengambilan sampel dilaksanakan di Desa Serang, Kecamatan Karangreja Kabupaten Purbalingga. Lokasi 1 dengan titik koordinat yaiu $7^{\circ}$ 13'40"LS 109 17'16" BT dengan ketinggian 1267 mdpl. Lokasi 2 dengan titik koordinat $7^{\Phi} 13^{\prime} 58^{\prime \prime}$ LS $109^{5}$ 16'52" BT dengan ketinggian 1249 mdpl. Isolasi dan identifikasi jamur penyebab penyakit dilaksanakan di Laboratorium Mikologi dan Fitopatologi Fakultas Biologi Universitas Jendral Soedirman Purwokerto, sedangkan Uji Postulat Koch dilakukan di green house Fakultas Biologi Universitas Jenderal Soedirman Purwokerto. Penelitian ini dilaksanakan selama 6 bulan mulai dari Oktober 2019 hingga Maret 2020.

\section{Rancangan Percobaan}

Penelitian ini menggunakan dua parameter, yaitu parameter utama dan parameter pendukung. Parameter utama meliputi jenis jamur penyebab penyakit bercak daun, dan persentase penyakit bercak daun pada tanaman sawi hijau yang disebabkan oleh jamur. Parameter pendukungnya meliputi suhu, kelembapan, dan $\mathrm{pH}$ tanah di lokasi penelitian.

\section{Cara Kerja Penelitian}

Pengambilan sampel dilakukan secara purposive random sampling. Lokasi yang digunakan sebanyak 2 lokasi. Lokasi 1 yang digunakan untuk pengambilan sampel memiliki luas lahan sekitar 12 m x 8 m dan lokasi 2, memiliki luas lahan 20 m x12 m dengan jarak tanam $20 \mathrm{~cm}$ x $20 \mathrm{~cm}$. Setiap lokasi secara diagonal di buat 5 petakan sehingga terdapat 10 petak untuk seluruh lokasi. Hasil yang diperoleh didokumentasikan secara langsung menggunakan kamera digital, kemudian dicatat tanda dan gejala dari masing-masing penyakit yang terlihat pada bagian tanaman dari setiap petak. Sampel diambil dengan jumlah yang sesuai berdasarkan hasil perhitungan menggunakan rumus dari Supranto (2000).

$$
n=\frac{N P Q}{(N-1) D+P Q}
$$

\section{Keterangan :}

$\mathrm{n}$ : Jumlah sampel yang diambil

$\mathrm{N}$ : Total tanaman dari dua lokasi

$\mathrm{P}$ : Tingkat Kesuksesan

$\mathrm{Q}$ : Tingkat Kegagalan dengan $\mathrm{Q}=1-\mathrm{P}$

$\mathrm{D}$ : Diambil berdasarkan rumus $B^{2} / 4$ dengan $\mathrm{B}$ sebagai batas atas kesehatan dan diperoleh berdasarkanbesarnya tingkat keyakinan.

\section{Deskripsi Penyakit}

Deskripsi penyakit dilakukan dengan mengamati tanaman yang sakit dengan melihat tanda dan gejala dengan menggunakan kaca pembesar, kemudian gejala penyakit dicocokkan meggunakan buku "Penyakit-Penyakit Tanaman Hortikultura di Indonesia" (Semangun, 1989). Hasil yang diperoleh didokumentasikan secara langsung menggunakan kamera digital, kemudian dicatat tanda dan gejala dari masing-masing penyakit yang terdapat pada bagian tanaman dari setiap petak dan data yang diperoleh ditabulasikan. 


\section{Menentukan Jenis Jamur yang Paling Banyak Muncul}

Jenis jamur yang paling banyak muncul pada tanaman sawi hijau dilihat melalui hasil frekuensi kemunculan dengan menghitung dan menjumlahkan masing-masing jenis jamur pada penyakit bercak daun yang ditemukan pada kedua lokasi pengabilan sampel. Jenis jamur yang paling banyak ditemukan pada kedua lokasi pengambilan sampel merupakan jenis jamur yang paling banyak muncul.

\section{Perhitungan Persentase Penyakit}

Persentase penyakit pada tanaman menurut Rahardjo \& Suhardi (2008) dihitung menggunakan rumus:

$$
p=\frac{a}{b} x 100 \%
$$

Keterangan :

$\mathrm{p}$ : Persentase penyakit

a : jumlah tanaman yang sakit.

B : jumlah tanaman yang diamati.

\section{Pembuatan Medium Potato Dextrose Agar (PDA)} (Maharani et al, 2014)

Kentang sebanyak 200 gram dipotong menjadi potongan dadu dan direbus dengan $500 \mathrm{ml}$ akuades hingga lunak, kemudian disaring untuk diambil ekstraknya. Dextrose sebanyak 20 gram dan 15 gram agar dilarutkan dengan menambahkan akuades sebanyak $200 \mathrm{ml}$. Setelah homogen larutan Dextrose dan agar ditambahkan ke dalam ekstrak kentang dan ditambah akuades hingga mencapai volume $1000 \mathrm{ml}$, kemudian dihomogenkan. Setelah media homogen ditambahkan chloramphenicol sebanyak $100 \mathrm{~g}$ atau 4 kapsul selanjutnya dihomogenkan kembali. Media yang sudah homogen dipindahkan ke dalam labu erlenmeyer, disterilisasi menggunakan autoclave selama 15-20 menit pada suhu $121-124 \circ \mathrm{C}$ dengan tekanan $2 \mathrm{~atm}$.

Isolasi dan Identifikasi Jamur Penyebab Penyakit Bercak Daun (Mukarlina \& Khotimah, 2014).

Jamur penyebab penyakit diisolasi dari sampel tanaman sakit dengan cara sampel daun sawi hijau sakit dipotong segi empat berukuran $1 \mathrm{~cm} \times 1$ $\mathrm{cm}$, pada bagian daun yang sakit dan yang sehat. Potongan-potongan tersebut disterilisasi dengan menggunakan alkohol 70\% selama kurang lebih 1530 detik, kemudian dibilas dengan akuades steril, di ambil secara aseptis dan dikeringanginkan di atas kertas tisu steril, setelah itu ditempatkan pada medium PDA di dalam cawan petri dan diinkubasi sampai terlihat pertumbuhan jamur. Hasil isolasi kemudian diremajakan untuk mendapatkan kultur murni, dengan cara menginokulasikan 1 ose isolat ke dalam medium PDA baru. Hasil peremajaan jamur kemudian diidentifikasi secara makromorfologi. Pengamatan karakter makromorfologi yaitu pengamatan secara langsung dengan melihat ciri koloni seperti warna, tekstur dan tepi koloni, serta pola penyebaran. Pengamatan karakter mikromorfologi yaitu dengan menggunakan mikroskop untuk mengamati karakteristrik jamur seperti tipe hifa (bersekat atau tidak), konidia (bentuk dan warna), dan konidiofor (bentuk dan warna). Hasil pengamatan dicocokkan dengan buku identifikasi "Illustrated Genera of Imperfect Fungi" (Bernett \& Hunter, 1972).

\section{Uji Postulat Koch (Suryanti et al., 2014)}

Penentuan patogen yang menyerang tanaman sawi hijau dilakukan dengan Uji Postulat Koch yang dilaksanakan di green house Fakultas Biologi Unsoed sebagai berikut Jamur patogen yang diperoleh dari hasil isolasi, masing-masing diinokulasikan pada 5 tanaman sawi hijau yang sehat. Jamur patogen diinokulasikan ke daun pada tanaman sawi hijau kemudian ditutup dengan plastik dan diinkubasi selama 7-10 hari. Gejala penyakit yang muncul diamati dan dibandingkan dengan gejala awal pada daun tanaman sawi hijau yang terinfeksi, gejala penyakit yang sama dengan gejala awal di daun sawi yang terinfeksi diambil bagian yang sakit untuk direisolasi. Bagian tanaman yang bergejala sakit tersebut di inokulasikan pada 
medium PDA dan diinkubasi hingga tumbuh jamur.

Hasil isolasi kemudian diremajakan untuk mendapatkan kultur murni. Jamur hasil isolasi diamati karakteristiknya dan dibandingkan dengan jamur isolasi patogen sebelumnya. Setelah diperoleh jamur patogen yang sama, dilakukan identifikasi secara mikroskopis. Pengamatan secara mikroskopis yaitu dengan menggunakan mikroskop untuk mengamati karakteristik jamur seperti hifa (bersekat atau tidak), konidia (bentuk dan warna), dan konidiofor (bentuk dan warna). Hasil pengamatan dicocokan dengan buku Identifikasi "Illustrated Genera of Imperfect Fungi" (Bernett \& Hunter, 1972) dan "Pictorial Atlas of Soil and Seed Fungi" (Watanabe, 2002).

\section{Pengukuran Faktor-Faktor Lingkungan.}

\section{Suhu dan Kelembapan}

Pengukuran suhu dan kelembapan lokasi penelitian di Desa Serang, Kecamatan Karangreja, Kabupaten Pubalingga dilakukan pada pagi hari pukul 07.00 dan sore hari pukul 17.00 dengan menggunakan termohygrometer setiap hari selama satu bulan. Pengukuran suhu dan kelembapan dilakukan dengan cara meletakkan termohygrometer pada tempat yang akan diukur suhu dan kelembapannya selama 3-5 menit dan selanjutnya diamati skala pada termohygrometer untuk mengetahui suhu dan kelembapannya

\section{Keasaman (pH) Tanah}

Pengukuran $\mathrm{pH}$ tanah dilakukan pada masing masing petak pada setiap lokasi pengambilan sampel dengan menggunakan soil tester. Cara penggunaannya adalah membasahi tanah dan menancapkan ujung alat ke tanah yang akan diukur, kemudian tombol ditekan dengan lama untuk mengukur $\mathrm{pH}$ tanah dan tidak menekan tombol untuk mengukur kelembapan tanah. Nilai pada bagian atas menunjukkan nilai $\mathrm{pH}$ tanah dan nilai yang di bawah menunjukkan nilai kelembapan tanah (dalam \%).

\section{Analisis Data}

Data utama yang diperoleh dianalisis secara deskriptif. Jenis penyakit yang ditemukan dideskripsikan berdasarkan tanda dan gejala yang terlihat pada bagian tanaman dengan menggunakan buku "Penyakit-Penyakit Tanaman Hortikultura di Indonesia" (Semangun, 1989). Jamur penyebab penyakit pada tanaman sawi hijau dideskripsikan dengan menggunakan buku identifikai "Illustrated Genera of Imperfect Fungi “ (Bernett \& Hunter, 1972) dan "Pictorial Atlas of Soil and Seed Fungi" (Watanabe, 2002). Persentase kemunculan penyakit bercak daun dihitung dengan menggunakan rumus Rahardjo \& Suhardi (2008). Hasil pengamatan ditampilkan dalam bentuk gambar yang telah didokumentasikan.

\section{HASIL DAN PEMBAHASAN}

Berdasarkan pengamatan dan hasil identifikasi morfologi pada tanaman sawi hijau (Brassica juncea) yang berada pada dua lokasi yang berbeda di Desa Serang, Kecamatan Karangreja, Purbalingga, di temukan satu jenis penyakit yaitu bercak daun. Gejala bercak daun (Gambar 1.A) yang di temukan pada pertanaman sawi hijau di Desa Serang ditandai dengan munculnya bercak berwarna coklat muda dengan bentuk yang tidak beraturan, kemudian semakin membesar dan meluas berwarna coklat tua yang lama kelamaan membentuk lingkaran kosentris, berdiameter 0.5-10 mm, sekitar bercak berwarna kekuningan, gejala ini biasanya ditimbulkan oleh jamur dari kelas Deutromycetes. Bercak daun adalah salah satu penyakit pada sawi hijau yang paling banyak menginfeksi dan merusak permukaan daun sawi hijau sedangkan pada Gambar 1.B adalah salah satu contoh daun sawi hijau yang sehat atau tidak memiliki bercak coklat konsentris. Penyakit bercak daun yang disebabkan oleh Alternaria sp. dapat menyebabkan kerugian hasil panen berkisar cukup besar antara 10-70 \% (Chadar et al., 2016). 

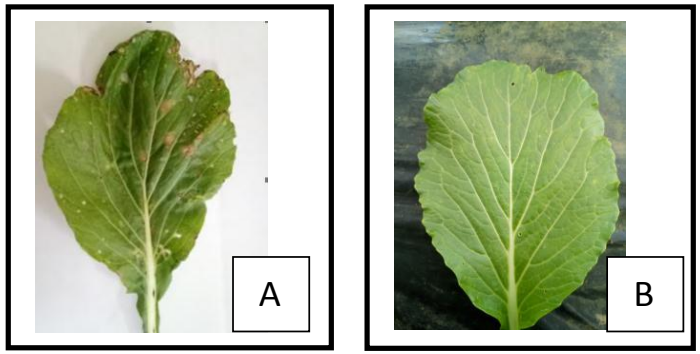

Gambar 1. Morfologi daun sawi hijau (Brassica juncea). Keterangan : (A) daun sawi hijau (berpenyait) memiliki gejala bercak daun (B). Daun sawi hijau sehat (tidak memiliki bercak daun).

Jamur Alternaria sp. memiliki karakteristik makroskopis seperti warna koloni hitam keabuabuan, Konidia berbentuk bundar (radial). permukaan koloni seperti kapas dengan Tepi koloni yang bergelombang dan kasar. hasil isolasi daun sawi hijau yang memiliki gejala bercak daun Alternaria sp. pada medium PDA, memiliki karakter makroskopis yaitu permukaan atas koloni berwarna putih keabu-abuan dan sebalik koloni berwana kehitaman (Gambar 2.A dan Gambar 2.B). pertumbuhan koloni keatas (Aerial), margin koloni bergerigi, Tekstur koloni seperti kapas, dan pola penyebaran radial, dapat dilihat pada Gambar 2.A dan Gambar 2.B pernyataan ini sesuai dengan penelitian Kumar et al. (2014).
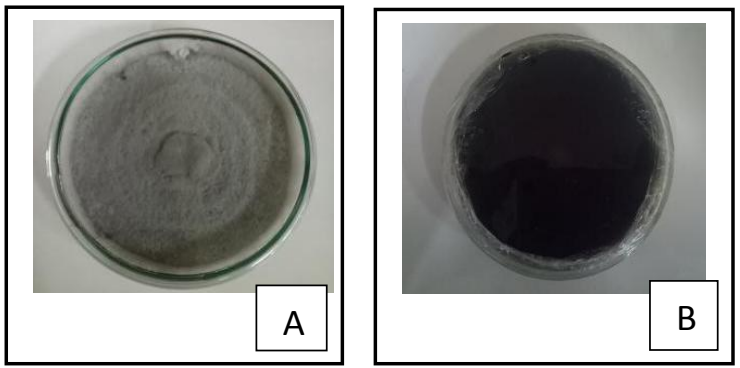

Gambar 2. Pengamatan makroskopis jamur Alternaria sp.

Keterangan : (A). Kenampakan Permukaaan atas koloni Alternaria sp. (B). Kenampakan sebalik koloni jamur Alternaria sp.

Hasil pengamatan secara makroskopis dan mikroskopis jamur penyebab penyakit pada tanaman sawi hijau ( $B$ juncea) di Desa Serang, Kecamatan Karangreja, Purbalingga adalah sebagai berikut :

Tabel 1. Hasil pengamatan makroskopis dan mikroskopis jamur patogen penyebab penyakit bercak daun pada tanaman sawi hijau (B juncea) di Desa Serang, Kecamatan Karangreja, Kabupaten Purbalingga pada lokasi 1 dan 2 .

\begin{tabular}{llc}
\hline No & Pengamatan & Jamur \\
\cline { 3 - 3 } & & A \\
\hline & Makroskopis & \\
\hline 1. & Warna permukaan koloni & Putih keabu-abuan \\
2. & Warna sebalik koloni & Hitam \\
3. & Tekstur koloni & Seperti kapas \\
4. & Margin koloni & Bergerigi \\
5. & Pola penyebaran koloni & Radial \\
6. & Pertumbuhan koloni & Aerial \\
\hline & Mikroskopis & \\
\hline 1. & Hifa (berseptat/aseptat) & Berseptat \\
2. & Pigmentasi hifa & Hyalin \\
3. & Bentuk hifa & Lurus dan bercabang \\
4. & Warna Konidiofor & Kecoklatan \\
5. & Bentuk konidia & Bulat telur $($ obclave $)$ \\
6. & Warna konidia & Kecoklatan \\
7. & Konidia (septat/aseptat) & Septat \\
8. & Panjang konidia & 7- $10 \mu \mathrm{m}$ \\
9. & Lebar konidia & $4-6 \mu \mathrm{m}$ \\
\hline & Hasil & Alternaria sp \\
\hline
\end{tabular}

Pengamatan jamur Alternaria sp, hasil isolasi secara mikroskopis pada Tabel 1 dilakukan dengan mengamati beberapa karakter mikromorfologi seperti jenis hifa dan konidia (septat/aseptat), konidiofor, bentuk konidia. Menurut Barnett \& Hunter (1972), jamur tersebut adalah jamur Alternaria sp. Kumar et al. (2014) menambahkan bahwa genus Alternaria mudah dibedakan dari 
genera jamur lainnya, dengan bentuk konidia yang besar dan gelap, berwarna coklat pucat/coklat. berbentuk bulat telur (obclavate). Berdasarkan Gambar 3.B jamur Alternaria sp. memiliki jenis hifa berseptat dengan pigmentasi warna hyalin, bentuk hifa memanjang dan bercabang, konidia berseptat berwarna kecoklatan, bentuk konidia bulat telur (obclavate), warna konidiofor kecoklatan (coklat pucat), panjang konidia 7-10 $\mu \mathrm{m}$ dan lebar konidia 4-6 $\mu \mathrm{m}$. Hal tersebut didukung oleh penelitian Chadar et al. (2016) yaitu konidia Alternaria sp. berwarna hitam kecoklatan dengan bentuk konidia bulat telur, ukuran konidia berkisar antara 10-13 $\mu \mathrm{m}$ dan lebar 3-8 $\mu \mathrm{m}$. Sedangkan menurut $\mathrm{Yu}$ et al. (2016) hifa Alternaria sp. berwarna coklat, konidiofor berwarna coklat muda, konidia berbentuk oval, panjang 18 - $29 \mu \mathrm{m}$ dan lebarnya 8 - $12 \mu \mathrm{m}$. Spesies ini pertumbuhannya lambat dan belum sempurna dalam membentuk klamidospora. Pembentukan spora terjadi pada suhu antara 8 $24^{\circ} \mathrm{C}$ tetapi kisaran suhu optimal antara $16-24^{\circ} \mathrm{C}$. (Kumar et al., 2014).
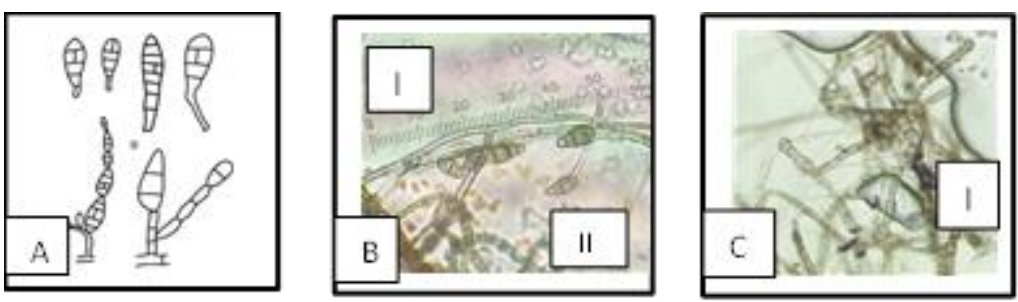

Gambar 3. Histologi jamur Alternaria sp.

Keterangan : (A). Gambar skematis bentuk konidia dan konidiofor jamur Alternaria sp. menurut buku Pictorial Atlas of Soil and Seed Fungi (Watanabe, 2002) (B). Hasil pengamatan jamur Alternaria sp. yang dilihat di bawah mikroskop cahaya terlihat (I: hifa dan II: konidia dari jamur Alternaria sp.) (C). Hasil pengamatan jamur Alternaria sp. yang dilihat di bawah mikroskop cahaya terlihat (I: konidiofor jamur Alternaria sp .

Tahapan selanjutnya setelah isolasi dan identifikasi adalah Postulat Koch. Jamur patogen hasil isolasi diinokulasikan pada permukaan atas daun sawi hijau yang sehat dan diamati selama 7 hari sampai ditemukan gejala yang menyerupai bercak daun awal. Gambar 4.A hasil inokulasi jamur patogen pada tanaman sawi hijau yang menunjukkan gejala bercak pada permukaan atas daun sawi hijau, yaitu adanya bercak bulat yang lama kelamaan membesar membentuk lingkaran kosentris dan pada bagian tengah lingkaran terbentuk daerah nekrosis. Menurut Simmons, (2007) daun yang terinfeksi jamur patogen selanjutnya di reisolasi atau diisolasi kembali.
Secara makroskopis pada Gambar 4.B permukaan atas koloni berwarna abu - abu kehitaman, tekstur koloni seperti kapas dengan tepi koloni rata dan pola penyebaran radial. Pengamatan mikroskopis (Gambar 4.C memiliki karekter yang sama dengan jamur yang diidentifikasi sebelumnya. Hasil Postulat Koch membukikan bahwa gejala yang ditimbulkan pada daun tanaman sawi hijau yang sehat setelah diinokulasikan jamur patogen memiliki karakter yang sama dengan jamur patogen yang diisolasi sebelumnya, maka jamur Alternaria sp. adalah jamur penyebab penyakit bercak daun pada tanaman sawi hijau. 

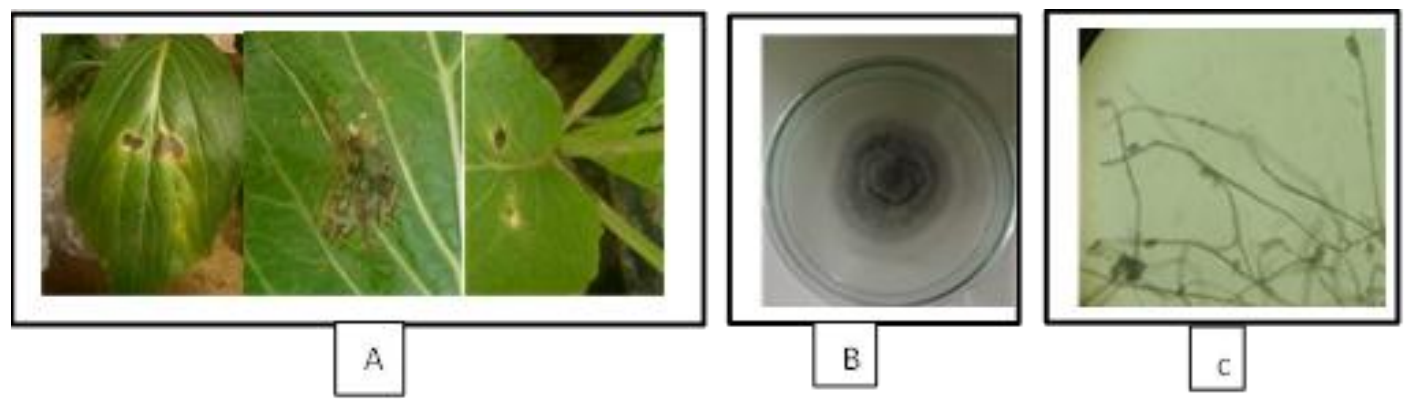

Gambar 4. Postulat koch dan reisolasi jamur Alternaria sp.

Keterangan : (A). Morfologi daun sawi hijau (Brassica juncea) yang sudah diinokulasikan jamur Alternaria sp. ( I: bercak daun Alternaria ) (B). Hasil reisolasi bercak daun setelah postulat koch. (C). Histologi jamur Alternaria sp hasil identifikasi yang diamati di bawah mikroskop cahaya ( 1: konidia jamur Alternaria sp).

\section{Frekuensi kemunculan penyakit}

Hasil perhitungan frekuensi kemunculan penyakit pada tiap lokasi penelitian dapat dilihat pada Tabel 2.

Tabel 2. Data frekuensi kemunculan tiap jenis penyakit yang disebabkan oleh jamur pada tanaman sawi hijau ( $B$ juncea) di Desa Serang, Kecamatan Karangreja, Kabupaten Purbalingga.

\begin{tabular}{ccccc}
\hline \multirow{2}{*}{ No } & \multirow{2}{*}{$\begin{array}{c}\text { Kode } \\
\text { penyakit }\end{array}$} & \multicolumn{2}{c}{ Frekuensi kemunculan } & Total \\
\cline { 3 - 4 } & Lokasi 1 & Lokasi 2 & \\
\hline 1. & A & 95 & 101 & 196 \\
\hline
\end{tabular}

Keterangan

A =bercak daun

Berdasarkan Tabel 2 Lokasi 2 enunjukkan frekuensi kemunculan penyakit bercak daun yang lebih besar dari lokasi 1 yaitu pada lokasi 2 sebanyak 101 tanaman yang berpenyakit sedangkan pada lokasi 1 terdapat 95 tanaman yang bergejala penyakit bercak daun. Perbedaan frekuensi kemunculan penyakit dipengaruhi oleh umur tanaman sawi hijau pada masing masing lokasi yang berbeda, menurut Semangun (1989), penyakit bercak daun pada Famili Brassicae umumnya menginfeksi pada tanaman yang berumur lebih tua, Pada lokasi 2 umur tanaman sawi hijau lebih tua dibandingkan dengan lokasi 1.

Penyakit yang ditemukan pada ke 2 lokasi yang berbeda hanya ditemukan penyakit bercak daun pada permukaan atas daun sawi hijau, sedangkan pada bagian akarnya tidak ditemukan gejala penyakit yang muncul seperti akar gada atau kaki hitam. Hal ini dipengaruhi oleh beberapa faktor lingkungan seperti: temperatur, kelembapan, $\mathrm{pH}$ tanah, dan sistem tanam yang diterapkan dalam bercocok tanam di Desa Serang, Kecamatan Karangreja, Purbalingga. Sistem pertanaman yang diterapkan di Desa Serang mayoritas menerapkan sistem tanam tumpang sari. Contohnya diketahui pada lokasi 1. tanaman sawi hijau ditanam tumpang sari dengan tanaman wortel sedangkan pada lokasi 2, sawi hijau ditanam tumpang sari dengan bawang daun. Tumpang sari merupakan sistem penanaman tanaman secara barisan diantara tanaman semusim dengan tanaman tahunan, Tumpang sari ditujukan untuk memanfaatkan lingkungan (hara, air dan sinar matahari) sebaik-baiknya agar diperoleh hasil yang maksimum (Jumin, 2011). Dalam pertanaman tumpangsari hasil tanaman secara keseluruhan lebih tinggi dari pada pertanaman monokultur apabila pemilihan kombinasi jenis tanaman sesuai dengan yang ditumpangsarikan (Ridwan, 2019).

Menurut Haryanto et al. (2003) bahwa tanaman sawi-sawian dapat ditumpangsarikan dengan bawang daun, bayam, kangkung darat, atau sayuran lainnya yang memiliki perakaran dangkal dan tajuk tidak terlalu lebar. Diketahui pada lokasi 1 yang digunakan dalam pengambilan sampel tanaman sawi hijau ditanam tumpang sari dengan tanaman wortel Sedangkan pada lokasi 2 yang digunakan sebagai tempat pengambilan sampel pada 
pertanaman sawi hijau di Desa Serang, kecamatan Karangreja, Purbalingga yaitu ditanam tumpang sari dengan tanaman bawang daun hal ini sesuai dengan pernyataan Haryanto et al. (2003). Tanaman bawang daun dapat digunakan untuk mengusir hama dikarenakan baunya yang khas. Tanaman bawang tergolong tanaman penolak hama (repellent). Menurut Nirmayanti (2014) tanaman (repellent) penolak organisme pengganggu tanaman (OPT) akan melindungi tanaman didekatnya dengan baubauan yang dikeluarkan oleh tanaman tersebut, bentuk dan warna daun atau bunga yang khas tidak disukai hama, sehingga hama akan menjauh dari tanaman utama.

Salah satu faktor lingkungan yang mempengaruhi munculnya penyakit bercak daun pada pertanaman sawi hijau yaitu suhu optimum infeksi jamur Alternaria sp. berkisar antara $20^{\circ}$ $30^{\circ} \mathrm{C}$ (Rotem, 1994). Adapula faktor-faktor lain seperti iklim, curah hujan, dan kelembaban telah terbukti mempengaruhi infeksi bercak daun Alternaria. sedangkan di Australia, penyakit terjadi pada musim panas yang hangat dan lembab (Thayer, 2005).

Hasil pengamatan temperatur selama 30 hari, berkisar antara $15^{\circ} \mathrm{C}-19^{\circ} \mathrm{C}$ pada pagi hari dan pada sore hari berkisar antara $19^{\circ} \mathrm{C}-22^{\circ} \mathrm{C}$, dengan kelembapan diatas $80 \%$ pada kedua lokasi yang berbeda dalam pengambilan sampel di Desa Serang, Kecamatan Karangreja, Purbalingga. Kondisi ini sesuai untuk perkembangan penyakit bercak daun Alternaria sp, Menurut Kumar et al. (2014) perkembangan spora Alternaria umumnya terjadi pada intensitas cahaya yang rendah dengan kelembapan sekitar 90\%. Hasil pengukuran derajat keasaman atau $\mathrm{pH}$ tanah pada lokasi penelitian netral, berkisar antara $(6,8-7)$. Menurut Meena et al. (2016) derajat keasaman $(\mathrm{pH})$ optimum untuk pertumbuhan misellium jamur Alternaria sp berkisar antara $\mathrm{pH}(5-8)$.

\section{Persentase penyakit jamur}

Berdasarkan frekuensi kemunculan penyakit jamur pada tanaman sawi hijau di Desa Serang, Kecamatan Karangreja, Purbalingga. maka diketahui hasil perhitungan total persentase penyakit pada dua lokasi yang berbeda sebagai berikut :

Tabel 3. Data persentase penyakit yang disebabkan oleh jamur pada pertanaman sawi hijau (B. Juncea) di Desa Serang, Kecamatan Karangreja, Purbalingga.

\begin{tabular}{cccc}
\hline No. & $\begin{array}{c}\text { Kode } \\
\text { penyakit }\end{array}$ & $\begin{array}{c}\text { Total kemunculan } \\
\text { (kali) }\end{array}$ & $\begin{array}{c}\text { ReratabPersentase } \\
\text { penyakit }(\%)\end{array}$ \\
\hline 1. & A & 196 & $51,30 \%$ \\
\hline
\end{tabular}

Keterangan

$\mathrm{A}=$ bercak daun

Hasil perhitungan frekuensi kemunculan dan persentase penyakit pada tanaman sawi hijau ( $B$ juncea) di Desa Serang, Kecamatan Karangreja, Kabupaten Purbalingga diketahui sebanyak 196 kali (Tabel 2) dengan persentase kemunculan penyakit mencapai angka 51,30 \% (Tabel 3). Menurut Leonart (2001), persentase penyakit kurang dari $50 \%$ belum dikatagorikan berbahaya, sedangkan pada persentase lebih dari $50 \%$ dapat dikatagorikan berbahaya dan perlu segera dikendalikan. Berdasarkan pengamatan di dua lokasi berbeda di Desa Serang, Kecamatan Karangreja, Purbalingga diketahui persentase penyakit bercak daun pada kedua lokasi sebesar 51,30 \% sudah di atas ambang batas maka perlu adanya pengendalian.

Pengendalian penyakit bercak daun pada pertanaman sawi hijau (B juncea) di seluruh dunia banyak menggunakan fungisida Iprodione karena sudah diuji sebagai bahan kimia yang paling ampuh dalam mengendalikan penyakit bercak daun Alternaria di Jepang, Cina dan India. Adapula fungisida lain seperti Mancozeb, Polyoxin, dan Hexaconazole (Sakurai \& Fujita, 1978). Selain itu dapat juga menggunakan pengendalian alternatif yaitu dengan menggunakan Agensia hayati, karena lebih murah, mudah didapat, dan aman terhadap 
lingkungan salah satunya adalah Trichoderma $\mathrm{sp}$ (Yudha et al., 2016)

\section{SIMPULAN}

Berdasarkan hasil dan pembahasan dapat disimpulkan bahwa terdapat satu jenis penyakit yaitu penyakit bercak daun yang disebabkan oleh jamur Alternaria sp. pada pertanaman sawi hijau di Desa Serang, Kecamatan Karangreja, Kabupaten Purbalingga. Frekuensi kemunculan penyakit bercak daun pada dua lokasi yang berbeda mencapai 196 kali, dengan rerata persentase penyakit bercak daun diatas ambang batas yaitu sebesar 51,30\% sehingga diperlukan pengendalian.

\section{DAFTAR REFERENSI}

Badan Pusat Stastistik Kabupaten Purbalingga., 2017. Purbalingga Regency in Figures. Purbalingga: BPS Stastics of Purbalingga Regency.

Barnett, H. L. \& Hunter, B. B., 1972. Illustrated Genera of Imperfect Fungi. Burgess. USA: Publishing company.

Chadar, L. K., Singh, R. P., Singh, R. K., Yadav, R. R., Mishra, M. K., Pratap, N., \& Vishnoi, R. K., 2016. Studies on Alternaria Blight of Rapeseed-Mustard (Brassica juncea L.) Caused by Alternaria brassicae (Berk.) Sacc. and its Integrated Management. Plant Archives, 16(2): 897-901.

Ekman, J, L Tesoriero, and S Grigg., 2014. Pests, Diseases, and Disorders of Brassica Vegetables a Field Identification Guide. Australia: Horticulture Australia.

Eshraghi, L., Barbetti, M. J., Li, H., Danehloueipour, N., \& Sivasithamparam, K., 2007. Resistance in Oilseed Rape (Brassica napus) and Indian Mustard (Brassica juncea) to a Mixture of Pseudocercosporella capsellae Isolates from Western Australia. Field Crops Research, 101(1): 3743.

Motlagh, MRS., 2011. Evaluation of Curvularia lunata as a Biological Control Agent in Major Weeds of Rice Paddies. Life science Journal. 8(2): 81-91.

Mukarlina, N. D, \& Khotimah, S., 2014. Penghambatan Pertumbuhan Jamur Fusarium oxysporum Schlecht pada Batang Padi (Oryza sativa L.) Menggunakan Ekstrak
Metanol Umbi Bawang Mekah (Eleutherine palmifolia Merr.). Protobiont, 3(2): 225-231.

Nirmayanti. F,. 2014. Pengaruh Beberapa Jenis Tanaman Pendamping Terhadap Hama Phyllotreta Striolata F. (Coleoptera: Chrysomelidae) Pada Budidaya Sawi Hijau Organik. Jurnal HPT, 3 (2): 2338-4336.

Pramila, P. G., Tasleem, M., Taj, G., Mal, R., \& Kumar, A., 2014. Morphological, Cultural, Pathogenic and Molecular Variability Amongst Indian Mustard Isolates of Alternaria brassicae in Uttarakhand. African Journal of Biotechnology, 13(3): 442-448.

Pratap, P., Meena, P. D., Singh, B. K., Meena, S. S., Sharma, P., Majumdar, R., \& Singh, D., 2016. Development and Evaluation of Alternaria Blight Tolerant Lines in Indian Mustard (Brassica juncea). Journal of Oilseed Brassica, 1(2):141-148.

Purnomo, D., Sakya, A. T., \& Fahrudin, F., 2012. Penggunaan Ekstrak Teh dan Pupuk Kacing pada Budidaya Caisim (Brassica juncea L.). Sains Tanah-Journal of Soil Science and Agroclimatology, 6(2): 61-68.

Rahardjo, I. B \& Suhardi., 2008. Insiden dan Serangan Penyakit Karat Putih Pada Beberapa Klon Krisan. J. Hort, 18(3): 312318.

Ridwan, M., 2019. Produktivitas Tumpangsari Beberapa Varietas Caisim dan Takaran Pupuk Kandang Ayam Dalam Pola Tumpangsari Tanaman Caisim dan Bawang Daun. Jurnal Sains Agro, 4(1): 258-074.

Rotem J,. 1994. The genus Alternaria: Biology, epidemiology, and pathogenicity. St. Paul, MN, USA: American Phytopathological Society Press

Rukmana, R., 1994. Bertanam Petsai dan Sawi. Kanisius: Yogyakarta..

Safitri, I, 2016. Studi Komparasi Usahatani Sayuran di Desa Kutabawa dan Desa Siwarak Kecamatan Karangreja Kabupaten Purbalingga. Geo Educasia-S1, 1(2): 4-15.

Sakurai H, \& Fujita S,. 1978. Antifungal Activity of Polyoxin B and Iprodione Against Phytopathogenic Fungi Recently Isolated from Diseased Plants in Japan. Pesticide Science 9: 207-12.

Sangadji, Z., 2018. Kajian Sistem Budidaya Tanaman Sawi (Brassica juncea L) di Petani Kelurahan Malawele Distrik Aimas Kabupaten Sorong. Median: Jurnal Ilmu Ilmu Eksakta, 9(1): 16-24 
Semangun, H., 1989. Penyakit-Penyakit Tanaman Hortikultura di Indonesia. Yogjakarta: Gajah Mada University press

Simmons EG., 2007. Alternaria: An Identification Manual. CBS Biodiversity Series No. 6, Utrecht, The Netherlands: 775.

Singh, D., Prasa, R., Yadav, S. P., \& Kumar, S., 2014. Characterization of Alternaria brassicae Causing Alternaria Blight of Rapeseed Mustard (Brassicae juncea L.) and it's Management. The Bioscan, 9(3): 12071212.

Suganda, T., \& Wulandari, D. Y., 2018. Curvularia sp. Jamur Patogen Baru Penyebab Penyakit Bercak Daun pada Tanaman Sawi. Agrikultura, 29(3): 119-123.

Supranto, J., 2000. Statistik Teori dan Aplikasi Jilid 1 ED 6, Jakarta: Erlangga.

Suryanti, U. Bintoro, V. P. Atmomarsono, U., Pramono, Y. B. \& Legowo, A. M., 2014. Antioxidant Activity of Indonesian Endogenous Duck Meat Marinated in Ginger (Zingiber officinale Roscoe) Extract. Int. J. Poult Sci. 13(2): 102-107.

Sutarman, S., 2017. Dasar Dasar Ilmu Penyakit. Sidoarjo: UMSIDA press.

Thayer CL., 2005. Plant disease forecasting and model validation: Classic and modern approaches. Raleigh, NC, USA: North Carolina State University, Master of Plant Pathology Thesis.
Wakeham, A. J., \& Kennedy, R., 2010. Risk Assessment Methods for the Ringspot Pathogen Mycosphaerella brassicicola in Vegetable Brassica crops. Plant disease, 94(7): 851-859.

Wangge, E. S., \& Fowo, M. F., 2012. Pengaruh Jarak Tanam Terhadap Pertumbuhan dan Hasil Tanaman Sawi Hijau (Brassica Juncea L). $A G R I C A, 5(1): 57-66$.

Watanabe, Tsuneo., 2002. Pictorial Atlas of Soil and Seed Fungi. America: CRC press.

Winarsih, D., Prihastanti, E., \& Saptiningsih, E., 2012. Kadar Serat dan Kadar Air serta Penampakan Fisik Produk Pascapanen Daun Caisim (Brassica juncea L.) yang Ditanam pada Media dengan Penambahan Pupuk Organik Hayati Cair dan Pupuk Anorganik. Bioma: Berkala Ilmiah Biologi, 14(1): 25-32.

Yu, Y., Zeng, L., Huang, L., Yan, Z., Sun, K., Zhu, T., \& Zhu, A., 2016. First Report of Black Leaf Spot Caused by Alternaria alternata on ramie in China. Journal of Phytopathology, 164(5): 358-361.

Yudha, M., Soesanto, L., \& Mugiastuti, E., 2016 . Pemanfaatan empat isolat Trichoderma sp. untuk mengendalikan penyakit akar gada pada tanaman caisin. Kultivasi, 15(3): 144149 